\title{
KADAR KALIUM SERUM PADA LATIHAN FISIK INTENSITAS SEDANG MAHASISWA FAKULTAS KEDOKTERAN UNIVERSITAS SAM RATULANGI
}

\author{
Dewa Agung Brihaspati Raj \\ Youla A. Assa \\ Murniati Tiho
}

\author{
Bagian Biokimia Fakultas Kedokteran Universitas Sam Ratulangi \\ bandas001@gmail.com
}

\begin{abstract}
Excessive body heat while doing physical exercise will be excreted by sweating. Potassium is one of the electrolyte compounds incorporated and washed away together with sweat. In turn, the excessive lost of potassium in sweat can decrease the concentration of extracellular potassium level. Physical exercise can also lead to an increase in serum potassium concentration. The present study was aimed to determine the differences of potassium level before and after physical exercise at moderate intensity at students year 2010 Faculty of Medicine Sam Ratulangi University. Thirty students (27 men and 3 women) were involved in the present pre-experimental study designed with pretest-posttest. Samples were colected using purposive sampling method and analyzed further using wilcoxon test. Data was collected by determine the serum potassium levels before and after moderate intensity physical exercise. Exercise is done in the form of fast walking on a treadmill to maintain heart rate target $64-76 \%$ of maximum heart rate (200 - age) for 30 minutes. The result showed that the average of serum potassium levels before moderate intensity exercise was $4,253 \pm 0,3683 \mathrm{mEq} / \mathrm{L}$, and the average of serum potassium levels after moderate intensity exercise was $4,363 \pm 0,3908 \mathrm{mEq} / \mathrm{L}$. Wilcoxon test significance values in this study were $\mathrm{p}=0.110(\mathrm{p}>0,05)$. It can be concluded that there was no difference of potassium level before and after physical exercise at moderate intensity at students year 2010 Faculty of Medicine Sam Ratulangi University.
\end{abstract}

Keywords: Potassium, Exercise, Moderate intensity.

Abstrak: Kelebihan panas tubuh saat melakukan latihan fisik akan dikeluarkan melalui keringat. Kalium merupakan salah satu elektolit yang terkandung dan dapat keluar bersama keringat. Kehilangan kalium yang berlebihan melalui keringat saat melakukan latihan fisik dapat menyebabkan penurunan konsentrasi kalium di dalam serum. Latihan fisik juga dapat menyebabkan peningkatan konsentrasi kalium. Penelitian ini bertujuan untuk mengetahui perubahan kadar kalium serum sebelum dan sesudah latihan fisik intensitas sedang pada mahasiswa Fakultas Kedokteran angkatan 2010 Universitas Sam Ratulangi. Penelitian ini merupakan penelitian pre-eksperimental dengan pretest-posttest design, dengan jumlah responden 30 mahasiswa (27 laki-laki dan 3 perempuan). Sampel dikumpulkan menggunakan metode purposive sampling dan dianalisis menggunakan uji Wilcoxon. Data dikumpulkan dengan menentukan kadar kalium serum sebelum dan sesudah melakukan latihan fisik intensitas sedang. Latihan fisik yang dilakukan berupa berjalan cepat di atas treadmill dengan mempertahankan target heart rate 64-76\% dari heart rate maksimal (200-umur) selama 30 menit. Hasil yang diperoleh menunjukkan bahwa rata-rata kadar kalium serum sebelum melakukan latihan fisik intensitas sedang ialah 4,253 $\pm 0,3683 \mathrm{mEq} / \mathrm{L}$, dan rata-rata kadar kalium serum sesudah melakukan latihan fisik intensitas sedang ialah 4,363 $\pm 0,3908 \mathrm{mEq} / \mathrm{L}$. Nilai signifikansi uji Wilcoxon pada penelitian ini ialah $\mathrm{p}=0,110(\mathrm{p}>0,05)$. Dapat 
disimpulkan bahwa tidak terdapat perbedaan yang signifikan antara kadar kalium serum sebelum dan sesudah latihan fisik intensitas sedang pada mahasiswa angkatan 2010 Fakultas Kedokteran Universitas Sam Ratulangi.

Kata kunci: Kalium, Latihan fisik, Intensitas sedang.

Latihan fisik adalah gerakan tubuh terencana, terstruktur, dan berulang-ulang yang dilakukan untuk meningkatkan atau mempertahankan satu atau lebih komponen kebugaran fisik (1). Latihan fisik atau aktivitas fisik yang dilakukan secara rutin dan aktif disertai dengan mengonsumsi makanan sehat bergizi dapat mencegah resiko terkena penyakit kronik dan meningkatkan kualitas hidup (2). Hasil survey oleh WHO pada tahun 2008 tentang aktivitas fisik di dunia, didapatkan 31\% orang dewasa dengan usia di atas 15 tahun kurang beraktivitas fisik (3). Hasil survey yang dilakukan di bagian gizi Fakultas Kedokteran Universitas Sam Ratulangi (4) yang mengambil responden mahasiswa dilaporkan bahwa 96\% responden mahasiswa memiliki karakteristik aktivitas fisik yang tergolong ringan dan 3\% responden mahasiswa memiliki karakteristik aktivitas fisik yang tergolong sedang.

Pada saat melakukan aktivitas atau latihan fisik, kelebihan panas tubuh yang terjadi saat peningkatan energi dan panas melalui proses metabolisme dan kontraksi otot akan dikeluarkan oleh air melalui keringat (5). Jumlah keringat yang dikeluarkan saat aktivitas atau latihan fisik dipengaruhi oleh kondisi lingkungan, intensitas dan durasi latihan (6). Keringat akan membawa elektrolit tubuh terutama natrium, kalium dan klorida. Keringat mengandung kosentrasi $\mathrm{K}^{+}$sekitar 5-8 mEq/L selama diinduksi dengan kondisi lingkungan yang panas. Pemain football Amerika yang melakukan sesi latihan selama dua jam dapat mengalami kehilangan hingga 5L keringat, dimana di dalam keringat tersebut mengandung $40 \mathrm{mEq} \mathrm{K}{ }^{+}$atau lebih, hal ini dapat berakibat terjadinya penurunan kadar kalium ekstraseluler sampai hipokalemia (7). Mohseni dkk (8) dalam penelitian menunjukkan bahwa terjadi satu kasus hipokalemia pada pelari setelah pertandingan marathon dari total 165 pelari.

Penelitian lain juga membuktikan bahwa kadar $\mathrm{K}^{+}$dapat meningkat selama melakukan latihan fisik. Peningkatan kadar $\mathrm{K}^{+}$ini disebabkan oleh $\mathrm{K}^{+}$keluar dari pembuluh darah, otot, dan sel darah (intraseluler) menuju ke ekstraseluer. Hal ini dapat menyebabkan terjadinya peningkatan kadar kalium pada ekstrasel sampai hiperkalemia. Hazar dkk (9) dalam penelitian menunjukkan bahwa terjadi peningkatan ringan kadar $\mathrm{K}^{+}$segera setelah latihan aerobik (shuttle run), dan satu jam setelah latihan aerobik (shuttle run) pada responden pria tetapi belum dapat dikatakan signifikan.

Peningkatan kadar kalium dapat menyebabkan hiperkalemia (Peningkatan konsentrasi kalium serum $>5,2 \mathrm{mEq} / \mathrm{L}$ ), sedangkan penurunan kadar kalium dapat menyebabkan hipokalemia (penurunan konsentrasi kalium serum $>3,5 \mathrm{mEql} / \mathrm{L}$ ). Peningkatan dan penuruan kadar kalium serum dapat menyebabkan gejala kehilangan nafsu makan, kelemahan otot, kram otot selama latihan, dan pada keadaan berat dapat terjadi aritmia jantung sampai kematian (10).

Intensitas dan durasi yang berbeda memiliki efek pada kadar elektrolit, karena telah terbukti dalam studi bahwa dapat terjadi perubahan kadar elektrolit sesuai dengan intensitas dan durasi latihan. Hazar dkk (9) dalam penelitian menunjukkan bahwa perubahan kadar elektrolit darah tidak signifikan pada pemain bola kaki sebelum, setelah dan satu jam setelah melakukan latihan aerobik (shuttle run). Koc (11) dalam penelitian juga menunjukkan perubahan kadar elektrolit tidak signifikan pada pemain bola tangan sebelum dan setelah kompetisi selama lima hari. 


\section{METODE PENELITIAN}

Penelitian ini merupakan penelitian pre-eksperimental dengan rancangan penelitian one group pre-post test. Penelitian ini dilaksanakan di tempat kebugaran fisik (gym), dan pemeriksaan darah dilakukan di Laboratorium. Variabel bebas dari penelitian adalah latihan fisik intensitas sedang, dan variabel terikatnya yaitu kadar kalium serum. Sampel diambil dengan metode purposive sampling sebanyak 30 orang yang memenuhi kriteria inklusi.

Definisi operasional kadar kalium serum adalah hasil yang didapat dari pengambilan darah vena tanpa puasa yang diperiksa dengan alat AVL 9180 electrolyte analyzer dengan metode elektroda ion selektif dapat diklasifikasi normal adalah 3,6-6,5 mEq/L. Latihan fisik intensitas sedang yaitu latihan fisik dengan berjalan cepat di atas treadmill dengan target denyut jantung $(H R) 64$ - 76\% dari denyut jantung maksimum $\left(H R_{\max }\right)$. Denyut jantung maksimum ( $H R_{\max }: 200$ - umur), $H R$ target $\left(64 \%-76 \% H R_{\max }\right)$, batas bawah $\left(64 \% H R_{\max }\right)$, batas atas $\left(76 \% H R_{\max }\right)$.

\section{Prosedur Pelaksanaan Penelitian}

Pengukuran dan pengambilan data dilakukan selama 4 hari. Hari pertama sampai hari ketiga masing-masing tiap harinya diikuti oleh 8 orang responden, dan hari terakhir diikuti oleh 6 orang responden. Suhu ruangan dipertahankan konstan Tahap-tahap persiapan dan pelaksanaan penelitian yang dilakukan setiap harinya ialah sebagai berikut:

a. Responden dikumpulkan di ruangan.

b. Menjelaskan maksud dan tujuan penelitian.

c. Menjelaskan prosedur penelitian.

d. Pengukuran frekuensi nadi dan tekanan darah pada semua responden.

e. Responden diminta untuk mengisi dan menandatangani informed consent.

f. Pengambilan darah I

g. Pemanasan selama 5 menit.

h. Peregangan selama 5 menit.

i. Latihan inti dengan berjalan cepat di atas treadmill selama 30 menit dengan mempertahankan heart rate sesuai dengan target heart rate, yaitu 64-76\% dari heart rate maksimal.

j. Pengambilan darah II

k. Pendinginan selama 5 menit.

l. Sampel darah dibawa sesegera mungkin ke laboratorium dan dilakukan pemeriksaan kadar kalium serum menggunakan metode Ion Selective Electrode (ISE).

\section{Pengolahan Data}

Data diolah menggunakan program SPSS (Statistical Package for the Social Sciences) dengan dianalisa menggunakan univariat (mean, median, standard deviation, minimum, dan maximum) dan bivariat dengan uji wilcoxon (wilcoxon test).

\section{HASIL}

Sampel penelitian ini berjumlah 30 orang, laki-laki terdiri dari 27 orang (90\%) dan perempuan 3 orang (10\%). Dari jumlah 30 responden, terdapat 12 orang (40\%) berusia 20 tahun, 16 orang (53\%) berusia 21 tahun, 1 orang (3\%) berusia 22 tahun, dan 1 orang (3\%) berusia 23 tahun (Tabel 1). 
Tabel 1. Distribusi frekuensi berdasarkan karakteristik responden

\begin{tabular}{lccc}
\hline \multicolumn{1}{c}{ Karakteristik Responden } & Jumlah & Presentasi (\%) \\
\hline \multirow{2}{*}{ Jenis kelamin } & Laki-laki & 27 & 90 \\
& Perempuan & 3 & 10 \\
\hline \multirow{2}{*}{ Umur (tahun) } & 20 & 12 & 40 \\
& 21 & 16 & 53,3 \\
& 22 & 1 & 3,3 \\
& 23 & 1 & 3,3 \\
\hline
\end{tabular}

Hasil analisis univariat kadar kalium sebelum melakukan latihan fisik intensitas sedang didapatkan rata-rata yaitu 4,253 $\mathrm{mEq} / \mathrm{L}$, standar deviasi 0,3683 , nilai tengah 4,2 $\mathrm{mEq} / \mathrm{L}$, nilai tertinggi 5,3 $\mathrm{mEq} / \mathrm{L}$, dan nilai terendah $3,6 \mathrm{mEq} / \mathrm{L}$. Hasil analisis univariat, didapatkan rata-rata kadar kalium sesudah melakukan latihan fisik yaitu 4,363 mEq/L, standar deviasi 0,3908, nilai tengah 4,3 mEq/L, nilai tertinggi 5,2 mEq/L, dan nilai terendah 3,6 mEq/L (Tabel 2).

Tabel 2. Hasil analisis univariat

\begin{tabular}{lcc}
\hline & $\begin{array}{c}\text { Sebelum latihan } \\
(\mathrm{mEq} / \mathrm{L})\end{array}$ & $\begin{array}{c}\text { Sesudah latihan } \\
(\mathrm{mEq} / \mathrm{L})\end{array}$ \\
\hline Mean & 4.253 & 4.363 \\
Median & 4.200 & 4.300 \\
Std. Deviation & 0.3683 & 0.3908 \\
Minimum & 3.6 & 3.6 \\
Maximum & 5.3 & 5.2 \\
\hline
\end{tabular}

Hasil uji wilcoxon pada penelitian ini menunjukkan nilai signifikansi $=0,110(>0.05)$. Berdasarkan hasil tersebut dapat diketahui bahwa hipotesis nol (H0) diterima dan hipotesis alternatif (H1) ditolak (Tabel 3).

Tabel 3. Hasil analisis bivariat (uji Wilcoxon)

\begin{tabular}{ccc}
\hline Sebelum latihan $(\mathrm{mEq} / \mathrm{L})$ & Sesudah latihan $(\mathrm{mEq} / \mathrm{L})$ & P value \\
\hline $4.253 \pm 0.3683$ & $4.363 \pm 0.3908$ & 0.110 \\
\hline
\end{tabular}

\section{BAHASAN}

Penelitian ini diikuti oleh 30 orang responden. Berdasarkan hasil analisis laboratorium kadar kalium serum sebelum dan sesudah latihan fisik didapatkan 30 responden dalam batas normal. Berdasarkan hasil penelitian didapatkan bahwa tidak ada perbedaan yang signifikan antara kadar kalium serum sebelum dan sesudah melakukan latihan fisik intensitas sedang. Hasil ini sama dengan penelitian yang dilakukan oleh Koc (11), dimana kadar kalium serum pada pemain handball setelah kompetisi handball tidak menunjukkan perubahan yang 
signifikan. Penelitian yang dilakukan oleh Hazar dkk (10) juga menunjukkan perubahan kadar kalium serum pada pemain bola kaki setelah melakukan latihan fisik aerobik yaitu sebelum, setelah dan 1 jam setelah latihan fisik aerobik tidak signifikan.

Durasi dan intensitas selama latihan fisik memiliki peranan dalam perubahan kadar elektrolit. Semakin lama durasi dan semakin tinggi intensitas dari latihan fisik yang dilakukan dapat menyebabkan meningkatnya jumlah air dan elektrolit seperti kalium yang dikeluarkan tubuh melalui keringat, durasi dan intensitas yang kurang bisa saja menjadi penyebab dari perubahan kadar kalium yang tidak signifikan. Hasil studi membuktikan durasi latihan yang kurang panjang sehingga tidak sampai menyebabkan dehidrasi, dapat menyebabkan kadar kalium akan kembali menjadi normal. Hal ini disebabkan oleh kalium yang akan terangkut kembali masuk ke dalam sel (intraseluler) selama pengukuran kadar elektrolit setelah melakukan latihan fisik (10).

Terdapat perbedaan pada penelitian ini dengan penelitian Hazar dkk (10) dan Koc (11) yaitu sampel pada penelitian ini ialah mahasiswa yang bukan atlet, sedangkan sampel pada penelitian Hazar dkk (10) dan Koc (11) ialah atlet bola kaki dan atlet bola tangan (handball). Sebagian besar atlet telah mengalami aklimatisasi. Aklimatisasi adalah suatu proses penyesuaian diri secara psikologis dan fisiologis terhadap suatu lingkungan yang baru (10). Setelah mengalami pemaparan terhadap latihan atletik secara progresif selama lebih dari satu sampai dua minggu pada awalnya akan terjadi aklimatisasi terhadap panas. Kemudian aklimatisasi akan terjadi juga pada kelenjar keringat, menyebabkan kehilangan elektrolit dalam keringat hanya sedikit dibandingkan sebelum berakllimatisasi. Aklimatisasi kelenjar keringat ini merupakan akibat peningkatan sekresi aldosteron oleh korteks adrenal. Aldosteron berpengaruh langsung terhadap sekresi kalium dalam urin dan keringat selama aklimatisasi panas. Aldosteron juga mempunyai pengaruh langsung terhadap reabsorpsi natrium dan klorida dari keringat sebelum keringat itu dikeluarkan dari tubulus kelenjar keringat ke permukaan kulit (12).

Secara umum pada penelitian ini diperoleh peningkatan kadar kalium serum setelah melakukan latihan fisik intensitas sedang, hasil ini sama dengan penelitian yang dilakukan oleh Hazar dkk (9) dimana terjadi peningkatan ringan kadar kalium pada responden pria setelah latihan aerobik dan 1 jam setelah latihan aerobik walaupun belum signifikan. Setelah melalui suatu latihan fisik atau kerja berat dalam durasi yang cukup panjang, kalium dapat dilepaskan dari otot rangka ke dalam cairan ekstrasel yang mengakibatkan terjadinya peningkatan kadar kalium ekstraseluler (9).

Terdapat juga beberapa hasil yang menunjukkan penurunan kadar kalium setelah melakukan latihan fisik intensitas sedang, hasil ini sama dengan penelitian yang dilakukan oleh Koc (11), dimana terjadi penurunan ringan kadar kalium setelah menyelesaikan kompetisi bola tangan (handball) walaupun tidak signifikan. Hal ini berarti bahwa kalium keluar bersama air melalui keringat selama melakukan latihan fisik. Aldosteron memegang peranan dalam peningkatan kehilangan kalium melalui keringat, aldosteron juga memiliki peran dalam perpindahan kalium dari ekstrasel ke dalam intrasel yang erat kaitannya dengan penurunan kadar kalium ekstrasel (12).

Pemberian cairan isotonik sebelum, selama, dan setelah melakukan suatu latihan fisik sangat penting untuk diperhatikan. Cairan tubuh yang terus menerus hilang melalui keringat selama melakukan latihan fisik akan akan menyebabkan peningkatan konsentrasi elektrolit pada ekstrasel dan selanjutnya menyebabkan dehidrasi pada sel. Hal ini akan mengganggu proses produksi Adenosin trifosfat (ATP) di dalam sel yang dibutuhkan untuk relaksasi otot, sehingga dapat menyebabkan kram otot dan kelemahan saat melakukan latihan fisik. Penggantian cairan yang hilang melalui keringat akibat latihan fisik penting untuk mencegah dehidrasi tersebut agar tidak terjadi (5). Pemberian cairan disertai elektrolit seperti kalium perlu diberikan apabila melakukan latihan fisik dengan durasi yang panjang dan pada 
lingkungan yang panas, karena pada keadaan tersebut memungkinkan untuk terjadinya perubahan pada kadar kalium sehingga dapat menimbulkan gejala seperti kelemahan, keram otot sampai aritmia jantung $(5,12)$.

Keterbatasan dalam penelitian ini yaitu jumlah sampel yang diteliti memenuhi jumlah minimal. Keterbatasan lain pada saat dilakukan penelitian yaitu suhu ruangan tempat dilakukannya penelitian sulit untuk dipertahankan agar tetap stabil. Suhu ruangan atau suhu lingkungan merupakan salah satu faktor yang mempengaruhi jumlah cairan dan elektrolit yang keluar melalui keringat. Tempat fitness atau gym yang digunakan juga memiliki ukuran yang kurang besar dan treadmill dengan jumlah yang terbatas.

\section{KESIMPULAN}

Berdasarkan penelitian yang telah dilakukan dapat disimpulkan bahwa tidak terdapat perbedaan signifikan kadar kalium serum sebelum dan sesudah latihan fisik intensitas sedang pada mahasiswa Fakultas Kedokteran Universitas Sam Ratulangi program studi pendidikan dokter umum angkatan 2010.

\section{DAFTAR PUSTAKA}

1. ACSM. Benefits and Risks Associated with Physical Activity. In: Thompson WR, Gordon NF, Pescatello LS, editors. ACSM's guidelines for exercise testing and prescription. Atlanta: Wolters Kluwer, 2009; p. 3-18; 153-82.

2. U. S. Department Of Health And Human Services. Physical Activity guidelines for americans. America; 2008. p. 1-5

3. WHO. Global recommendations on physical activity for health. Switzerland: The Institute, 2010. p. 41-54.

4. Thirtayasa IH. Hubungan Antara Aktivitas Fisik Dengan Status Gizi Mahasiswa Angkatan 2011 Program Studi Pendidikan Dokter Universitas Sam Ratulangi [skripsi]. Manado:Universitas Sam Ratulangi;2012.

5. Irawan MA. Konsumsi cairan dan olahraga. PsspLabs [serial di internet]. 2007 [dikutip 2013 Sep 11]. Tersedia URL: http://www.pssplab.com/journal/02.pdf.

6. Sawka MN, Burke LM, Eichner ER, Maughan RJ, Montain SJ, Stachenfeld NS. Exercise and fluid replacement. ACSM. 2007;337-90.

7. Unwin RJ, Luft FC, Shirley DG. Pathophysiology and management of hypokalemia: a clinical perspective. Nat Rev Nephrol. 2011;7:75-84. 
8. Mohseni M, Silvers S, McNeil R, Diehl N, Vadeboncoeur T, Taylor W. Prevalence of hyponatremia, renal dysfunction, and other electrolyte abnormalities among runners before and after completing a marathon or half marathon. Sports Med. 2011;3(2):145-51.

9. Hazar M, Sever O, Gurkan AC, Er NF, Erol M. Physiologic responses of macro elements to maximal aerobic exercise in male and female footballers. Life Sci J. 2013;10(6):734-37.

10. Fink HH, Burgoon AL, Mikesky AE. Partical applications in sports nutrition. Ontario: Jones and Bartlett Publishers; 2006. p. 190-220.

11. Kос Н. The effect of acute excercises on blood electrolyte values in handball players. Afr J Pharm Pharmacol. 2011;4(1):93-97.

12. Guyton AC, Hall JE. Buku ajar fisiologi kedokteran (Edisi 11). Irawati, Ramadhani D, Indriyani F, Dany F, Nuryanto I, Rianti S, alih bahasa. Jakarta: EGC, 2008; p. 383-400; 1111-23. 